\title{
Warning of 'research crisis' at German universities
}

Munich. Germany's independent science advisory council, the Wissenschaftsrat, warned last week that the quality of research in German universities is facing a crisis because of reduced funding, inflexible attitudes and increasing teaching burdens.

The Wissenschaftsrat says that urgent measures are needed to safeguard universities' research potential if the traditional 'Humboldt principle', which emphasizes the maintained. The warning is delivered in a series of ten 'theses' - a traditional means of expression in academic circles that dates back to Martin Luther.

In a message directed mainly at federal and regional politicians, the council says that more investment is needed to modernize university laboratories, which, in nearly all disciplines, have become increasingly neglected since the expansion of universities that began in the 1960 s.

Student numbers in Germany have almost doubled since 1980. Yet there has been no growth in university budgets, or in the number of academic staff. Greater student numbers not only force academic staff to spend more time teaching but also divert investment away from laboratories. The situation has now reached crisis point, according to the Wissenschaftsrat.

As a result, Germany's most talented researchers generally prefer to work in better equipped non-university research institutes, such as those of the Max Planck Society. This is particularly true in east Germany, where university research was discouraged in communist times, and also in high-technology disciplines in which equipment needs to be continually updated.

But money alone is not the answer, says the Wissenschaftsrat. Its theses also urge universities to shed inflexible attitudes that blind them to the fact that modern research is increasingly interdisciplinary and international.

The high degree of independence given need to link teaching and research, is to be

to faculties is partly to blame, it says, because it encourages competition between faculties, rather than cooperation in establishing interdisciplinary research programmes. Universities should avoid internal squabbling and focus their energies on competing in a more global sense.

Research sabbaticals should not be an automatic privilege but should be awarded on merit, and a university's budget should be distributed on merit, rather than being divided fairly evenly between disciplines.

The council also says that university research must acknowledge new social demands, more positions must be found for young woman scientists, and university scientists should become more involved in public debates on the acceptability of certain areas of research.

The University Rectors' Conference (HRK) has welcomed the theses, which mirror its own long-standing concerns about standards of university research laboratories. Josef Langer, general secretary of HRK, says that the situation is deteriorating, with cuts by Land (regional) governments to their universities averaging well over 5 per cent this year.

But not everyone feels that tight budgets are undermining the quality of research. Christoph Schneider, spokesman for the Deutsche Forschungsgemeinschaft (DFG), the organization that distributes competitive research money to universities, says that the research body "sees too many good research proposals passing through [the DFG] to recognize an impending danger for university research".

Nevertheless, DFG accepts that it is difficult to encourage talented scientists to return to Germany after postdoctoral experience in the United States. It has recently launched a 'young scientist programme', which will pay for young biologists who are deemed to be excellent to return to Germany and set up their own research groups in universities.

Alison Abbott

\section{Illegal sale of research ship prompts review}

Moscow. The presidium of the Russian Academy of Sciences has been reviewing the future of its research fleet after one of the vessels, Hydrobiolog, was sold off without permission. The ship was leased by its owner, the P. Shershov Oceanology Institute, to a private company for gathering coral off the coast of Tunisia. But the businessmen registered the vessel in Tunisia, then changed its name and finally sold it illegally.

Nikolai Laverov, vice-president of the academy, says that the academy allowed the ship to fly the Tunisian flag to avoid paying taxes, because otherwise the leasing would have been uneconomic. But the businessmen took advantage of this permission and fraudulently sold the ship.

The academy itself has been keen to sell off some of its old ships to support the newer ones, but at present this is impossible as all the vessels are part of the scientific research fleet. The academy is going to withdraw this status from the Zarya, Aquanavt and Aquanavt-2.

Carl Levitin

\section{Engineering academy agrees compensation for deposed president}

Washington. The US National Academy of Engineering (NAE) has agreed to pay $\$ 687,500$ to Harold Liebowitz, who was recently deposed as president, as compensation for his removal from office one year into a four-year term.

The academy, whose main activity is to provide the US government with advice on technical problems, also expects to incur legal costs of $\$ 300,000$, bringing the total cost of Liebowitz's departure to almost $\$ 1$ million.

Liebowitz, a former home secretary of the academy, stood for president twice as a 'rebel' candidate running against the established order in the NAE. He complained that the academy was neglecting its membership of 2,000 élite engineers, and failing to assert itself relative to its larger and more powerful scientific counterpart, the National Academy of Sciences (NAS).

He won the second time, in April 1995, but soon clashed with staff at the National Research Council - the operating arm of the two academies - as well as with senior officials at both NAE and NAS. In May, the council of the NAE won backing from the

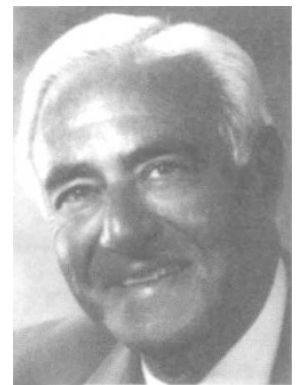

Liebowitz: voted out of office by NAE members. membership for a rule change that enabled the membership to vote Liebowitz out of office (see Nature 380, 471; 1996). William Wulf, acting president of NAE until new elections are held, says the agreement with Liebowitz will bring an end to the episode. But he says it has taught the academy to pay more attention to its members.

"I don't think there is any question that the academy needs to be more responsive to its membership, and that is what we are now doing," says Wulf. Liebowitz, who has withdrawn all of his various legal actions against the academy complex and its officers in exchange for the settlement, was unavailable for comment.

An undisclosed portion of the settlement will be paid by the NAE's insurance. Some of the rest will come out of overhead charges on the academy complex, and up to $\$ 325,000$ from the NAE's endowment funds, which is currently worth $\$ 40$ million.

Wulf justifies making Liebowitz's payment out of the money paid by the US government as overhead costs on federal contracts on the grounds that "legal fees are part of the natural cost of doing business".

Colin Macilwain 